\title{
Flavonoids Synthesized in Cortical Cells During Nodule Initiation Are Early Developmental Markers in White Clover
}

\author{
Ulrike Mathesius, ${ }^{1}$ Cathy Bayliss, ${ }^{2}$ Jeremy J. Weinman, ${ }^{1}$ Helmi R. M. Schlaman, ${ }^{3}$ Herman P. Spaink, ${ }^{3}$ \\ Barry G. Rolfe, ${ }^{1}$ Margaret E. McCully, ${ }^{2}$ and Michael A. Djordjevic ${ }^{1}$ \\ ${ }^{1}$ Plant Microbe Interactions Group, Research School of Biological Sciences, G.P.O. Box 475, Australian \\ National University, Canberra ACT 2601, Australia; ${ }^{2}$ Department of Biology, Carleton University, 1125 \\ Colonel By Drive, Ottawa, Canada K1S 5B6; ${ }^{3}$ Institute of Molecular Plant Science, Leiden University, \\ Clusius Laboratory, Wassenaarseweg 64, 2333 AL Leiden, The Netherlands \\ Accepted 2 September 1998.
}

\begin{abstract}
We examined the site-specific induction of the flavonoid pathway before and during nodule initiation in white clover with transgenic plants, fluorescence microscopy, and microspectrofluorometry to test if flavonoids play a role in nodule organogenesis. A chalcone synthase regulated $\beta$ glucuronidase (GUS) transgene (CHS3:gusA) was upregulated from $3 \mathrm{~h}$ post inoculation (p.i.) until cell division (around $40 \mathrm{~h}$ p.i.) in inner cortex cells underlying the inoculation site. Intracellular fluorescence occurred in vacuoles of those inner cortex cells from $13 \mathrm{~h}$ p.i. until the fluorescent cells divided. Fluorescence emission spectra of contents of individual fluorescing cortex cells were measured in situ and compared with emission spectra of compounds purified from root extracts. The fluorescing compound located in cells of the inner cortex after Rhizobium leguminosarum bv. trifolii infection was identified as a wa-

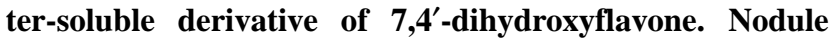
primordium cells contained a different fluorescent compound, identified as the isoflavonoid formononetin. CHS3:gusA expression and flavonoid accumulation were only induced in inner cortex cells by a nodulating Rhizobium strain and by clover-specific lipo-chitinoligosaccharides, but not by non-nodulating rhizobia. Fluorescence was also induced by compatible rhizobia in other legumes such as alfalfa, pea, and siratro in the cells that participate in nodule initiation. Our results show that fluorescent flavonoids are useful markers in nodule organogenesis in clover and may have direct roles in nodule formation.
\end{abstract}

Additional keywords: auxin transport inhibitor, nod gene inducer, secondary signals, signal transduction.

Soil bacteria of the genera Rhizobium, Bradyrhizobium, Mesorhizobium, Sinorhizobium, and Azorhizobium, generically called rhizobia, induce root nodules on legume plants. Rhizobia induce nodule organogenesis by producing lipochitin oligosaccharides (LCOs) (Dénarié et al. 1996; Spaink et

Corresponding author: Michael A. Djordjevic; Telephone: 61-2-62493088; Fax: 61-2 6249-0754; E-mail: Michael@ rsbs.anu.edu.au al. 1995), which induce cell divisions in inner (indeterminate nodulation) or outer (determinate nodulation) root cortex cells. The divided cells then form a nodule primordium that later differentiates into the mature nodule (Spaink 1996).

It is not known how LCOs induce cell divisions in certain cells of the root cortex. Because cell divisions in the plant are regulated by phytohormones, especially auxin and cytokinin, LCOs could interfere with the phytohormone balance (Bauer et al. 1996; Hirsch et al. 1989; Hirsch 1992). One possible mechanism could be through the inhibition of polar auxin transport during nodule initiation (Mathesius et al. 1998). However, because the structure of the LCO molecule is very different from any known auxin transport inhibitor, it is unlikely that the LCO molecule itself acts directly in this role. Rather, specific plant flavonoids could act as secondary signals that alter the auxin balance (Hirsch 1992). Mathesius et al. (1998) showed that the application of flavonoid aglycones, LCOs, or a synthetic auxin transport inhibitor onto or into the root led to similar changes in the expression of an auxin responsive reporter construct (GH3:gusA) in the stele within hours. Specific flavonoid aglycones inhibit auxin transport in zucchini hypocotyls (Jacobs and Rubery 1988), whereas flavonoid glycosides are inactive.

Several reports demonstrated that flavonoid production (Lawson et al. 1996; Recourt et al. 1992; Schmidt et al. 1994) and flavonoid gene expression are induced both prior to (Krause et al. 1997; Lawson et al. 1994; McKhann et al. 1997; Savouré et al. 1997) and during nodule formation (Charrier et al. 1995; Yang et al. 1992). Excreted flavonoids induce bacterial nodulation genes (Redmond et al. 1986) that are responsible for LCO biosynthesis. So far, flavonoids have not been localized during the earliest stages of nodule organogenesis.

If flavonoids mediate the action of LCOs via a localized and/or transient perturbation of the auxin balance, the induction of flavonoid gene expression should precede the shifts in the auxin balance and flavonoid accumulation should spatially correlate with the inferred changes in auxin levels observed (Mathesius et al. 1998). To find out if rhizobia induce flavonoids at the site of infection, we used two approaches to investigate the induction of the flavonoid pathway in space and time during the earliest stages of nodule initiation in white 
clover. First, we examined the expression of chalcone synthase (CHS), which encodes the first enzyme of the flavonoid pathway (Stafford 1990). The genes encoding CHS occur as a multigene family in clover (Arioli et al. 1994). We examined the expression of a $C H S$ promoter $(C H S 3)$ fused to the gus $A$

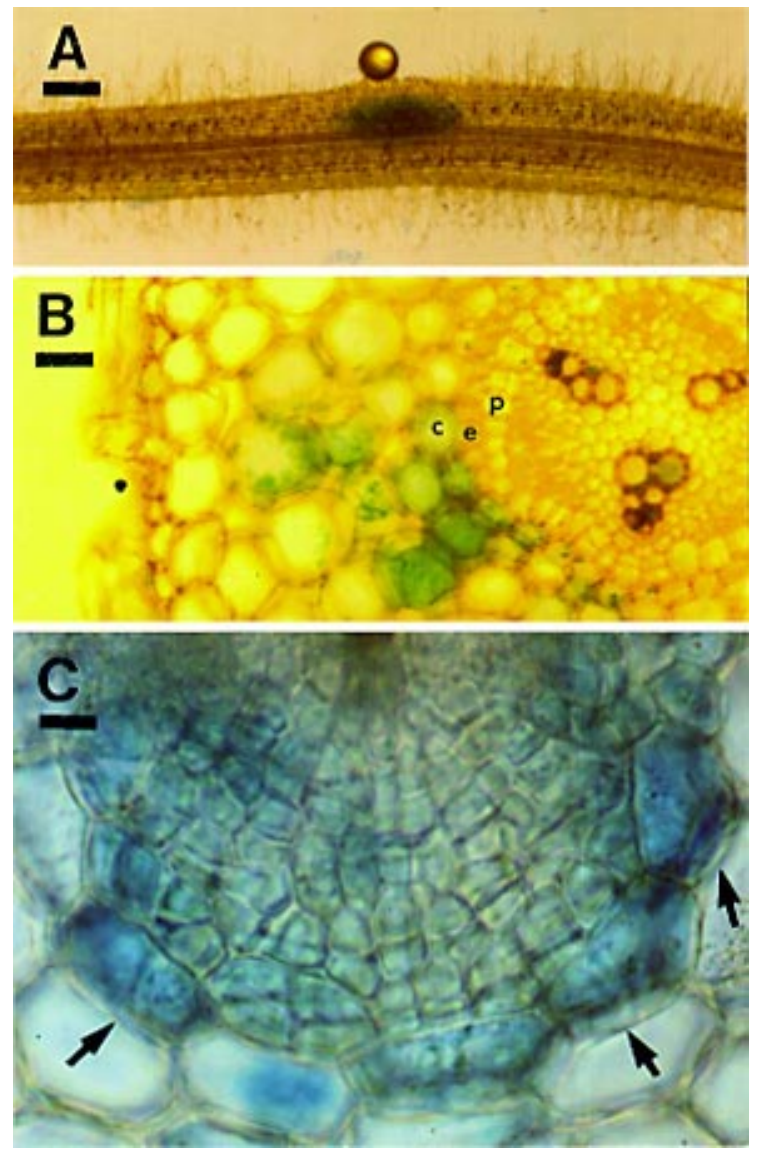

Fig. 1. Expression of CHS3: gusA in transgenic white clover roots during the first 4 days of nodule initiation. A, Spot-inoculated root $30 \mathrm{~h}$ post inoculation (p.i.). CHS3:gusA expression is induced at the inoculation site, marked with a bead, between 3 and 40 h p.i. with strain ANU843. $\mathbf{B}$, A transverse section at the inoculation site of the root shown in $\mathbf{A}$ shows that CHS3:gusA expression occurs mainly in inner cortex cells (p $=$ pericycle, $\mathrm{e}=$ endodermis, $\mathrm{c}=$ cortex $). \mathbf{C}$, A nodule primordium 4 days after inoculation shows CHS3:gusA expression in some cells of the primordium and mainly in the cortex cells in front of the primordium that have not yet divided (arrows). Bars $=$ (A) $500 \mu \mathrm{m}$; (B) $50 \mu \mathrm{m}$; (C) $25 \mu \mathrm{m}$. reporter gene in transgenic white clover plants. Second, to find out whether end products of the flavonoid pathway were localized in the same cells in which $C H S$ induction occurred, we examined the contents of these cells in situ by fluorescence microscopy and microspectrofluorometry. Microspectrofluorometry has been developed to localize fluorescent compounds in cells following anhydrous substitution (Bayliss et al. 1997). This method has been simplified by using thick, fresh root sections and analyzing fluorescent contents of the intact cells. The fluorescent spectra of the cell contents were compared with those of flavonoids isolated from root extracts and commercial standards. Potential fluorescent flavonoids were also detected in live tissue sections by applying the fla-

Table 1. Results from spot inoculation of nodulating, mutant, and heterologous bacterial strains and lipo-chitin oligosaccharides (LCOs) onto roots containing the CHS3: gusA reporter construct

\begin{tabular}{|c|c|c|c|c|}
\hline \multirow{2}{*}{$\begin{array}{l}\text { Spot inoculated } \\
\text { strain or substance }\end{array}$} & \multirow{2}{*}{$\begin{array}{l}\text { Incubation } \\
\text { time (h) }\end{array}$} & \multirow{2}{*}{$\begin{array}{c}\text { Total no. } \\
\text { of treated } \\
\text { or control } \\
\text { roots }^{\mathrm{a}}\end{array}$} & \multicolumn{2}{|c|}{$\begin{array}{l}\text { Roots with } \\
\text { positive response }^{\mathrm{b}}\end{array}$} \\
\hline & & & Inoc. & Control \\
\hline \multirow{6}{*}{$\begin{array}{c}\text { Rhizobium leguminosarum } \\
\text { bv. trifolii ANU843 }\end{array}$} & 3 & 12 & 2 & 0 \\
\hline & 5 & 12 & 5 & 0 \\
\hline & 10 & 16 & 6 & 0 \\
\hline & 20 & 18 & 11 & 0 \\
\hline & 30 & 25 & 11 & 1 \\
\hline & 50 & 25 & 15 & 0 \\
\hline \multirow[t]{4}{*}{ LCOs of strain ANU843 } & 3 & 13 & 3 & 0 \\
\hline & 5 & 15 & 13 & 0 \\
\hline & 20 & 19 & 12 & 0 \\
\hline & 60 & 8 & 7 & 0 \\
\hline \multirow[t]{2}{*}{ ANU277(nodC::Tn5) } & 5 & 10 & 0 & 0 \\
\hline & 24 & 14 & 0 & 0 \\
\hline \multirow[t]{2}{*}{ ANU845(pSym-) } & 5 & 10 & 0 & 1 \\
\hline & 24 & 11 & 0 & 0 \\
\hline \multirow[t]{2}{*}{$\begin{array}{l}\text { Sinorhizobium meliloti } \\
\quad \text { ANU1080 = Rm } 1021\end{array}$} & 5 & 10 & 2 & 0 \\
\hline & 24 & 15 & 1 & 0 \\
\hline \multirow{2}{*}{$\begin{array}{l}\text { Bradyrhizobium japonicum } \\
\text { USDA110 }\end{array}$} & 5 & 12 & 5 & 0 \\
\hline & 24 & 13 & 2 & 1 \\
\hline \multirow{2}{*}{$\begin{array}{l}\text { R. leguminosarum bv. vi- } \\
\text { ciae ANU } 300\end{array}$} & 5 & 11 & 4 & 0 \\
\hline & 24 & 10 & 0 & 0 \\
\hline \multirow[t]{2}{*}{ Escherichia coli $\mathrm{C} 600$} & 5 & 15 & 0 & 0 \\
\hline & 24 & 15 & 0 & 0 \\
\hline
\end{tabular}

${ }^{a}$ Equal numbers of control and treated roots were examined.

${ }^{\mathrm{b}}$ Number of inoculated (Inoc.) or control roots in which a positive response occurred (local CHS3:gusA expression at site of inoculation as shown in Figure 1A) out of total number of inoculated roots.

Fig. 2. Intracellular fluorescence in fresh root sections at the inoculation site. A-I, Sections of white clover roots. J, Pea root. K, Siratro root. A, C, D, E, $\mathbf{G}, \mathbf{H}$, and $\mathbf{J}$, Sections incubated with diphenylboric acid-2-aminoethyl ester (DPBA). I, Section incubated in $\mathrm{NH}_{4} \mathrm{OH}$. Roots were spot inoculated with strain ANU843 unless stated otherwise. A, 5 h post inoculation (p.i.). Orange fluorescing cortex cells (arrows) occur in inoculated or uninoculated roots. B, Mature region of a control root contains occasional autofluorescing cortex cells (arrows) in front of xylem poles. Some pericycle cells (p) also fluoresce. C, 24 h p.i. Orange fluorescing inner cortex cells appear between and in front of two xylem poles. A single outer cortex cell also fluoresces (arrow). D, $40 \mathrm{~h}$ p.i. Orange fluorescing undivided inner cortex cells just prior to beginning of cell division. One cell has just divided (arrow). E, $72 \mathrm{~h}$ p.i. Area of orange fluorescing cortex cells spans half the root circumference. Several inner cortex cells have divided (arrows). Both the divided and some undivided cells in front of the divided cells show orange fluorescence. Nuclei of cells undergoing division are enlarged and fluoresce. Some pericycle cells (p) also fluoresce. F, $96 \mathrm{~h}$ p.i. Cells of a young nodule primordium fluoresce blue (arrow head); undivided outer cortex cells in front of the primordium fluoresce orange (arrow). This section was counter-stained with toluidine blue so that cell walls appear blue. G, $120 \mathrm{~h}$ p.i. Primordium extends toward outer cortex. Outer cortex cells retain orange fluorescence after their division (arrow). H, $24 \mathrm{~h}$ p.i. with lipo-chitin oligosaccharides (LCOs) of strain ANU843. Orange fluorescence occurs in several inner cortex cells. I, 24 h p.i. with Sinorhizobium meliloti. Orange fluorescence occurs in outer cortex cells only. J, Pea root section $120 \mathrm{~h}$ p.i. Underlying the (fluorescing) inoculation bead (b) on the root surface, inner cortex cells fluoresce nce yellow. Some cells have just divided (between arrows). K, Siratro root section $48 \mathrm{~h}$ p.i. showing blue fluorescence in outer cortex cells underlying inoculation bead (b). Bars = (A and C) $100 \mu \mathrm{m} ;(\mathbf{B}, \mathbf{E}, \mathbf{H}, \mathbf{I}, \mathbf{J}$, and $\mathbf{K}) 50 \mu \mathrm{m} ;(\mathbf{D}, \mathbf{F}$, and $\mathbf{G}) 30 \mu \mathrm{m}$. 
vonoid-specific reagent diphenylboric acid-2-aminoethyl ester (DPBA; Pietrzak and Collins 1996) or after treatment with $\mathrm{NH}_{4} \mathrm{OH}$, which can shift the fluorescent properties of flavonoids (Schnabl et al. 1986).

We also looked for flavonoid induction during the interaction of white clover with purified LCOs or a range of nonnodulating mutant and clover-incompatible rhizobia. Several other legumes were also investigated to find out if flavonoid induction during earliest stages of nodulation is a general phenomenon.

\section{RESULTS}

Rapid expression of $\mathrm{CHS}$ occurs in response to Rhizobium leguminosarum bv. trifolii inoculation in inner cortical cells of white clover.

Inoculated transgenic white clover plants containing the CHS3:gusA were examined. Mock-inoculated control roots expressed CHS3:gusA only in the root tip and emerging lateral roots (data not presented). Plants spot inoculated at the zone of emerging root hairs with the Rhizobium leguminosarum bv.
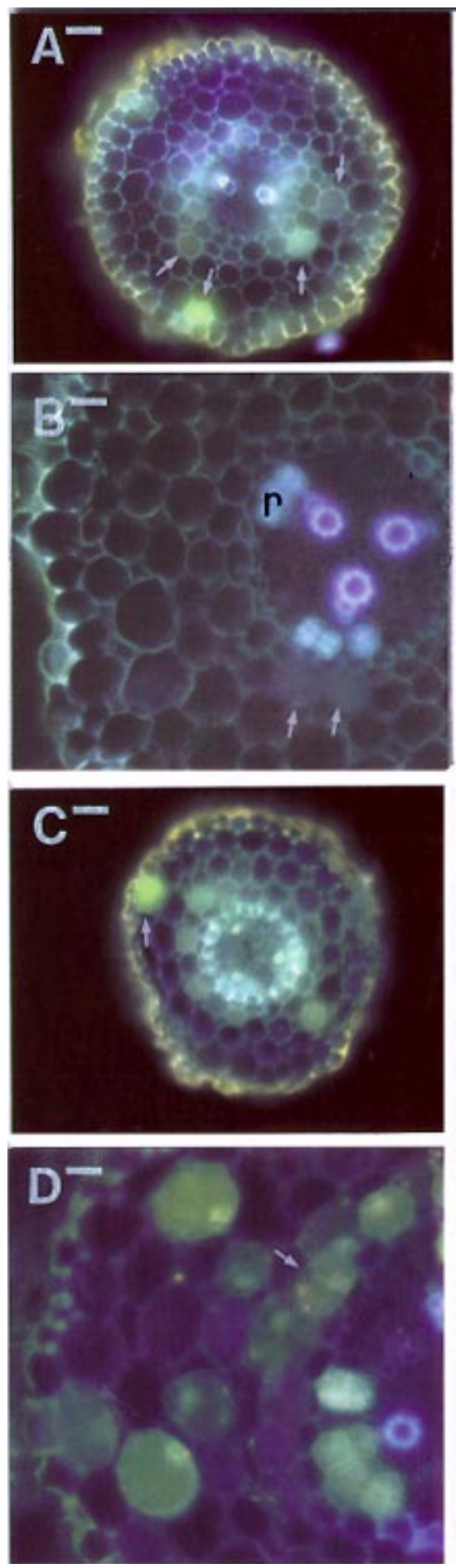
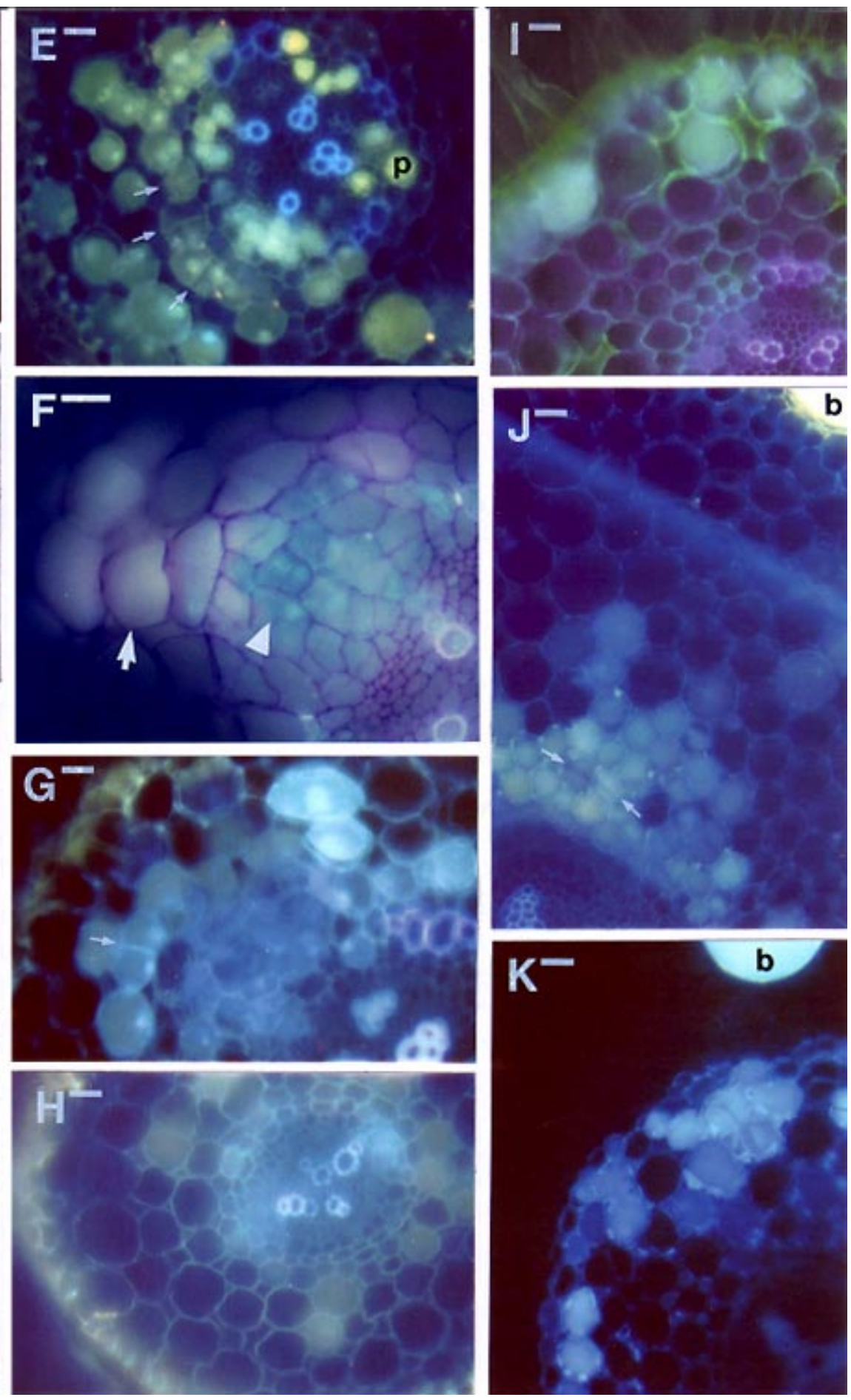
trifolii strain ANU843 (which led to a $>90 \%$ probability of nodule formation at the marked site) expressed CHS3:gusA in the inner cortex cells underlying the site of inoculation from 3 until $50 \mathrm{~h}$ post inoculation (p.i.) (Fig. $1 \mathrm{~A}$ and B, Table 1). The young nodule primordium also expressed CHS3:gusA in some of the dividing cells, but expression was mainly seen in the undivided outer cortex cells adjacent to the divided cells (Fig. 1C). CHS3:gusA expression was largely absent in mature nodules (data not presented).

\section{Intracellular fluorescence occurs in cells that participate in nodule organogenesis in white clover.}

When sections of fresh tissue made at different stages of nodule initiation were examined for autofluorescence, several randomly distributed cortex cells close to the site of either inoculation or mock-inoculation contained blue intracellular autofluorescence at 0 and $5 \mathrm{~h}$ p.i. at the site of inoculation. This fluorescence shifted to an orange color after DPBA treatment and will subsequently be referred to as "orange fluorescence" (Fig. 2A). In control roots between 10 and $120 \mathrm{~h}$ p.i., most mature cortex cells did not fluoresce, except that occasionally some cortex cells in front of the xylem poles and in the outer cortex had blue autofluorescence (Fig. 2B). In contrast, in roots inoculated with strain ANU843, the number of fluorescing cortex cells increased from $13 \mathrm{~h}$ p.i. until about $40 \mathrm{~h}$ p.i., visible as distinct groups of orange fluorescing inner cortex cells underlying the site of inoculation (Fig. 2C). These groups of orange fluorescing cortex cells occurred between, and in front of, xylem poles.

Cells from within the groups of orange fluorescing inner cortex cells began to divide around $40 \mathrm{~h}$ p.i., suggesting that the orange fluorescence found between 13 and $40 \mathrm{~h}$ p.i. occurs in the progenitor cells of a nodule primordium. All the newly divided cells retained the orange fluorescence seen in inner cortex cells before cell division (Fig. 2D). Between 40 and 50 $\mathrm{h}$ p.i., the area containing orange fluorescing cortex cells widened, comprising more and more divided cells that spanned half of the circumference of the root (Fig. 2E). Half of the 25 nodule primordia examined spanned at least half the circumference of the root, again suggesting that the enlarged area of orange fluorescing cortex cells seen between 40 and $50 \mathrm{~h}$ p.i. matched the location of the future nodule primordium. Of the remaining primordia examined, two thirds occurred in front of a xylem pole and one third between two xylem poles.

After the formation of a small nodule primordium (between 50 and $70 \mathrm{~h}$ p.i.), we observed that the divided cells of the primordium contained a blue autofluorescence that remained blue after DPBA treatment. These centrally located cells were surrounded by orange fluorescing cells that had just divided or were about to be "recruited" into the growing nodule (Fig. 2F). These peripheral orange fluorescing cells divided (around $120 \mathrm{~h}$ p.i.), retaining their orange fluorescence just after division (Fig. $2 \mathrm{G})$. Orange fluorescence was also detected in outer cortex cells harboring infection threads (data not presented). Orange fluorescence was retained in cells plasmolyzed in sucrose solution, suggesting its location is in the vacuoles of these cells.

\section{Different flavonoids occur in cortical cells at distinct developmental stages.}

Fluorescence emission spectra of cell contents were obtained in situ from the individual fluorescing cortex cells de- scribed above. To identify the compounds responsible for the typical fluorescence observed, we extracted the total roots and purified each fluorescent compound by high-pressure liquid chromatography (HPLC). We found seven fluorescent compounds. Fluorescence emission spectra of each of the compounds were obtained and compared with the spectra obtained in situ from individual cells. Spectra of fluorescing compounds are subject to the conditions in the cell (e.g., $\mathrm{pH}$ ) and may be difficult to compare with spectra of compounds dissolved in water alone. Therefore, we recorded spectra under three different conditions: first as autofluorescence; second after addition of DPBA to untreated sections or the dissolved compounds; and third after addition of $\mathrm{NH}_{4} \mathrm{OH}$ to untreated sections or the dissolved compounds.

We found two distinct types of spectra in the cell contents of cortex cells at different stages of development. The first type of spectrum was characterized by blue autofluorescence (maximum emission $\left(\mathrm{E}_{\max }\right)=450 \mathrm{~nm}$; Fig. 3A). After treatment with DPBA, the blue autofluorescence was shifted to orange fluorescence with $\mathrm{E}_{\max }$ at 460 and $520 \mathrm{~nm}$ (Fig. 3B), and after separate treatment with $\mathrm{NH}_{4} \mathrm{OH}$, it was shifted to a fluorescence with a single $\mathrm{E}_{\max }$ at $520 \mathrm{~nm}$ (Fig. 3C). This spectrum was recorded from the cell contents of fluorescing cells in the inner cortex at $24 \mathrm{~h}$ p.i. that had not yet divided (orange fluorescing cells shown in Figure 2C) (Fig. 3). This spectrum was also recorded from the cell contents of fluorescing inner cortex cells at $70 \mathrm{~h}$ p.i. that had just divided or were adjacent to just divided cells (orange cells shown in Figure $2 \mathrm{D}$ and $\mathrm{E}$ ) and from cortex cells of control and inoculated roots just behind the root tip (orange cells shown in Figure 2A). The spectra of one of the purified compounds, named "compound 3," matched the spectra of the cell contents of inner cortex cells in the absence (Fig. 3A) or presence of either DPBA (Fig. 3B) or $\mathrm{NH}_{4} \mathrm{OH}$ (Fig. 3C). Compound 3 was water soluble (Fig. 4A), and after hydrolysis of the compound in acid we determined that the hydrolysis product (Fig. 4B) was $7,4^{\prime}$-dihydroxyflavone (DHF). The identity of DHF was determined by co-chromatography with commercial standards. In addition, both retention time (Fig. 4C) and absorbance spectra of DHF and the hydrolysis product of compound 3 were identical (Fig. 4E). The absorbance spectrum of compound 3 was slightly different from that of the absorbance spectrum of the aglycone (Fig. 4D). Therefore, we conclude that the orange fluorescence that is made in inner cortex cells during the initiation of a nodule primordium and in cortex cells just behind the root tip is due to the presence of a derivative of DHF in the vacuoles of these cortex cells.

The second type of spectrum (Fig. 5) was recorded from the cell contents of blue fluorescing cells in young nodule primordia between 70 and 120 h p.i. (as shown in Figure 2F and G). The autofluorescence showed an $\mathrm{E}_{\max }$ at $460 \mathrm{~nm}$ (Fig. 5A). After incubation in DPBA, most cells showed a major peak at $460 \mathrm{~nm}$ and a minor peak at 500 to $510 \mathrm{~nm}$ (Fig. 5B), but transitions between the spectrum shown in Figures $3 \mathrm{~B}$ and $5 \mathrm{~B}$, with variable ratios of the peaks at 460 and $510 \mathrm{~nm}$, were present in primordia at different stages. After treatment with $\mathrm{NH}_{4} \mathrm{OH}$ the $\mathrm{E}_{\max }$ was at $460 \mathrm{~nm}$ (Fig. 5C). These spectra matched those obtained from another compound purified from extracts of control roots and from roots bearing small nodule primordia under all three conditions (Fig. 5A-C). The second compound was identified as the isoflavonoid formononetin by 
co-chromatography with commercial standards. Both the retention time and absorbance spectra of the purified compound and commercially available formononetin were identical (data not presented).

\section{R. leguminosarum bv. trifolii LCOs induce CHS3:gusA} expression and fluorescence in clover inner cortex cells.

To find out whether the induction of flavonoids in clover is specific to the nodulation process, we spot inoculated LCOs isolated from strain ANU843 onto transgenic roots. The
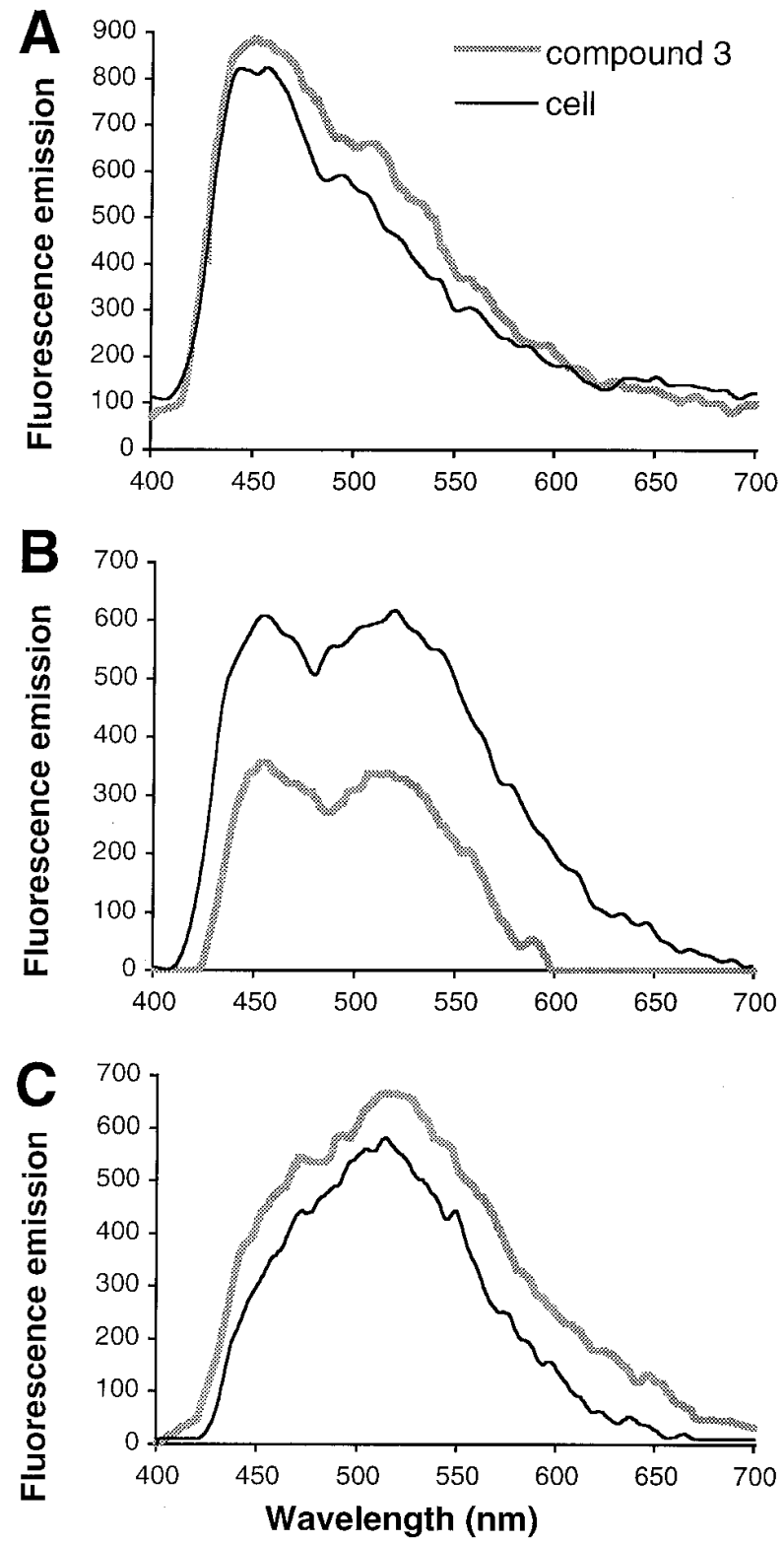

Fig. 3. Comparisons of fluorescence emission spectra recorded from fluorescent contents of inner cortex cells of white clover roots $24 \mathrm{~h}$ post inoculation (p.i.) with strain ANU843 ("cell") with spectra recorded of a water-soluble compound ("compound 3") extracted from white clover roots. Fluorescence emission is measured in arbitary units. A, Autofluorescence spectra. B, Spectra recorded after addition of diphenylboric acid-2-aminoethyl ester (DPBA) to either untreated root sections or to dissolved compound 3. C, Spectra recorded after addition of $\mathrm{NH}_{4} \mathrm{OH}$ to either untreated sections or the dissolved compound 3.
CHS3:gusA expression was induced within $3 \mathrm{~h}$ of inoculation with LCOs, and local CHS3:gusA expression was visible until $60 \mathrm{~h}$ p.i. (Table 1). The CHS3:gusA expression was always located in the inner cortex directly underlying the site of in-
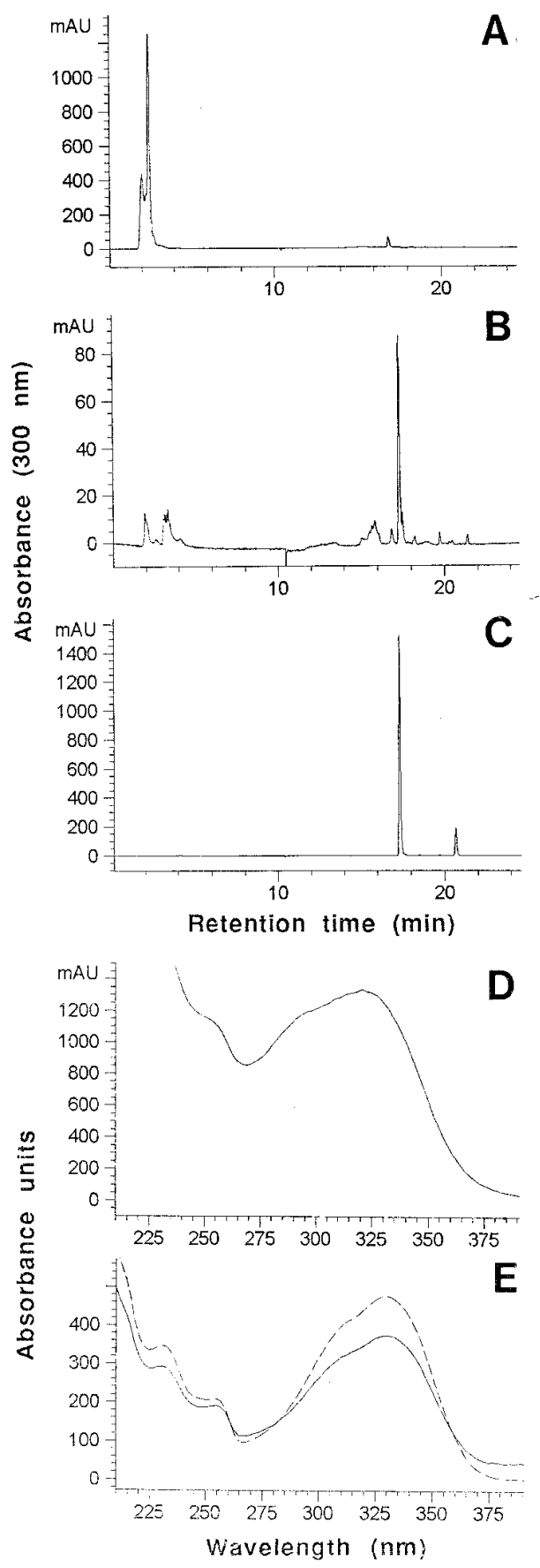

Fig. 4. High-pressure liquid chromatography (HPLC) and spectral analysis of compound 3. A, HPLC chromatogram of compound 3 before hydrolysis. The compound is eluted in water. B, HPLC chromatogram of hydrolysis product of compound 3. The major product is eluted in 50\% acetonitrile. Some minor reaction products also appeared in the product. C, HPLC chromatogram of 7,4'-dihydroxyflavone (DHF; major peak). The little peak was an impurity of the commercially available DHF. D, Absorbance spectrum of compound 3. E, Absorbance spectrum of the hydrolysis product of compound 3 (unbroken line) compared with absorbance spectrum of DHF (dashed line). 
oculation, consistent with the location of gusA expression following inoculation with strain ANU843 (similar to Figure $1 \mathrm{~A}$ and B). Similarly, DPBA-enhanced orange fluorescence was induced in the inner cortex by the addition of the LCOs to white clover within $24 \mathrm{~h}$ p.i. (Fig. $2 \mathrm{H}$ ). The spectra of the fluorescing compounds induced in inner cortex cells after LCO inoculation were similar to the spectra of compounds induced by ANU843. Even though single-spot inoculations of LCOs did induce CHS3:gusA expression and accumulation of orange fluorescence in the inner cortex, it did not lead to cell
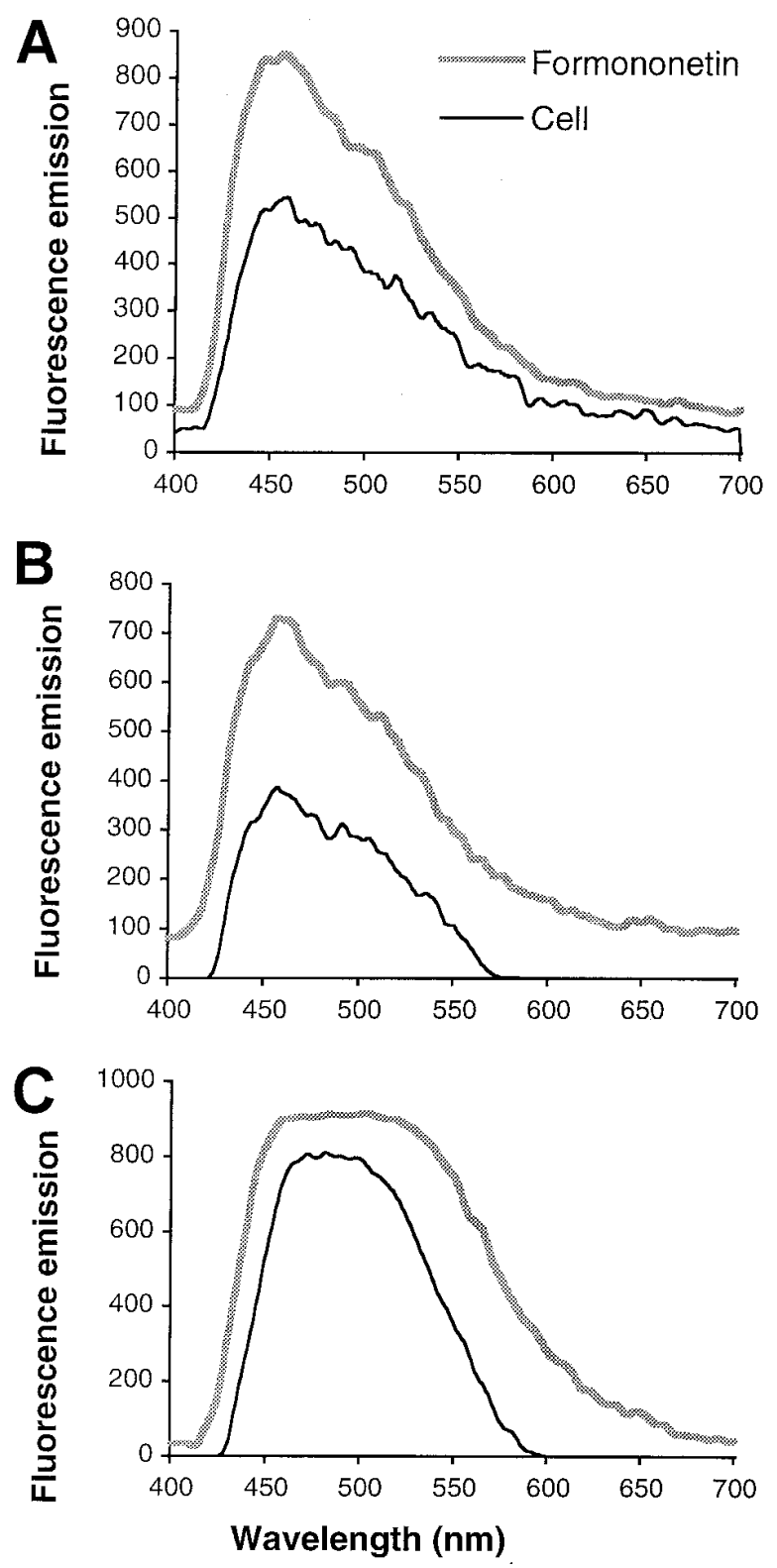

Fig. 5. Comparisons of fluorescence emission spectra recorded from fluorescent contents of nodule primordium cells of white clover $70 \mathrm{~h}$ post inoculation (p.i.) with strain ANU843 ("cell") with spectra recorded from formononetin. Fluorescence emission is measured in arbitary units. A, Autofluorescence spectra. B, Spectra recorded after addition of diphenylboric acid-2-aminoethyl ester (DPBA) to either untreated root sections or dissolved formononetin. C, Spectra recorded after addition of $\mathrm{NH}_{4} \mathrm{OH}$ to either untreated sections or dissolved formononetin. divisions in the inner cortex. LCO inoculation only led to cell divisions in the inner cortex after repeated inoculation (four times) over 2 days at the same site. Past the $48 \mathrm{~h}$ timepoint, orange fluorescence was only sustained in inner cortex cells undergoing division when LCOs were repeatedly spot inoculated.

\section{Non-nodulating bacteria fail to induce nodule-specific fluorescence patterns and $\mathrm{CHS3:gusA}$ expression in clover inner cortex cells.}

To determine whether the induction of fluorescence and CHS3:gusA observed during the stages preceding nodule initiation was a specific response of the plant to a nodulationproficient Rhizobium strain, we inoculated several mutant or heterologous rhizobia onto white clover roots. $\mathrm{Nod}^{-}$mutants of strain ANU843 that are unable to make LCOs, strains ANU277(nodC::Tn5) and strain ANU845 (a Sym-plasmid deleted strain) (McKay and Djordjevic 1993), failed to induce both CHS3:gusA expression and accumulation of fluorescence in inner cortex cells underlying the inoculation site (Table 1). Heterologous rhizobia (Sinorhizobium meliloti, R. leguminosarum bv. viciae, and Bradyrhizobium japonicum) induced CHS3:gusA expression at lower rates than ANU843 (Table 1). All three non-homologous wild-type strains induced some orange fluorescence in outer cortex cells (Fig. 2I), but not in inner cortex cells. No induction of CHS3:gusA or induction of fluorescence was observed after spot inoculation of Escherichia coli (Table 1).

We then compared the increase in the number of fluorescing inner and outer cortex cells $24 \mathrm{~h}$ after spot inoculation of the different bacterial strains and LCOs in a 1-mm segment at the site of inoculation, using analysis of variance. There was a significant $(P<0.05)$ increase in the number of fluorescent inner cortex cells only after inoculation of the nodulating $R$. leguminosarum bv. trifolii and LCOs purified from that strain, but not after inoculation of any non-nodulating strain (Fig. 6).

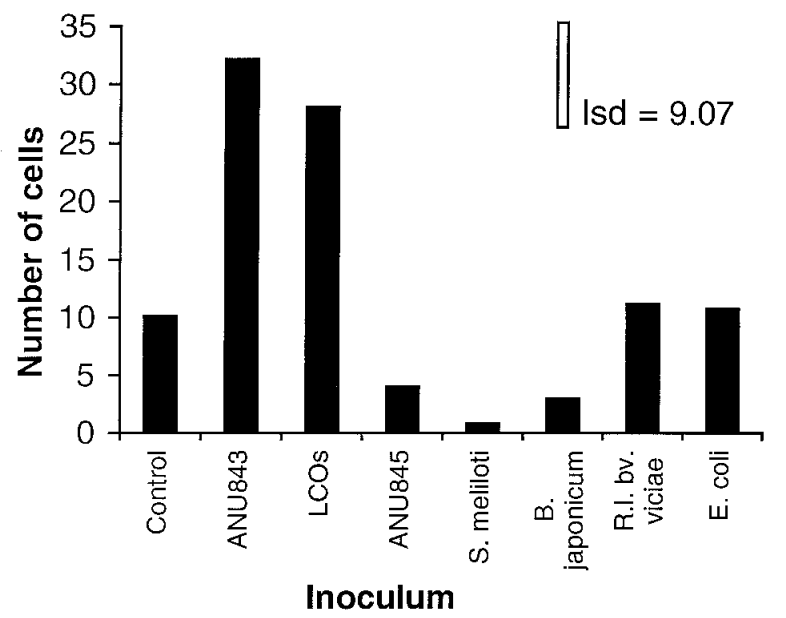

Fig. 6. The number of fluorescent inner cortex cells at the inoculation site in a root segment within $1 \mathrm{~mm}$ of the inoculation site. Spotinoculated white clover roots were sectioned $24 \mathrm{~h}$ post inoculation (p.i.). For each inoculum the fluorescent cortex cells in 10 sections of $120 \mu \mathrm{m}$ thickness each were counted and 5 roots analyzed. Analysis of variance showed a significant increase $(P<0.05)$ in the number of fluorescent inner cortex cells induced by strain ANU843 and lipo-chitin oligosaccharides (LCOs) of strain ANU843. The "lsd" bar represents the least significant difference between any two inocula. 
We found no significant $(P>0.05)$ effect of any inoculum on the number of fluorescent outer cortex cells.

\section{Intracellular fluorescence in nodule progenitor cells is a common feature of legumes.}

To determine if the occurrence of fluorescent flavonoids in cells participating in nodule formation was a feature unique to white clovers, we examined nodule ontogeny in several other legumes, including pea and alfalfa (indeterminate nodulation) and siratro and soybean (determinate nodulation). In pea and alfalfa, intracellular fluorescence was induced in groups of inner cortex cells underlying the inoculation bead (Fig. 2J) before and during cell division (from 24 until 120 h p.i.). Fluorescence was subsequently also seen in divided inner cortex cells and, in pea, in outer cortex cells harboring the infection thread(s). In siratro, autofluorescence was induced in outer cortex cells underlying the site of inoculation (Fig. 2K) and in cells that subsequently divided to form the nodule primordium. In soybeans, extensive background autofluorescence occurred in most cortex cells of uninoculated and inoculated roots, which made it difficult to see possible changes in the inoculated roots. However, blue fluorescence was seen in young soybean nodules. The identity of fluorescent compounds in these species is likely to be different from those found in white clover and will require further studies.

\section{DISCUSSION}

\section{The activation of the flavonoid pathway is one} of the earliest responses to nodulation-competent rhizobia.

Our results show that induction of the flavonoid pathway and the accumulation of compounds with specific flavonoidlike properties in different cell types are very early responses of clover roots to the application of nodulation-competent rhizobia or clover-specific LCOs. The activation of CHS3:gusA was site specific, occurring in the inner cortex cells underlying the inoculation site. The CHS3:gusA induction can be detected within $3 \mathrm{~h}$, indicating a very rapid signal transduction from the root surface to the inner cortex cells. The results of Savouré et al. (1997), who showed CHS induction within 30 min after inoculation of Medicago sativa roots with LCOs, are consistent with our findings. The activation of CHS3:gusA in precisely the cells underlying the inoculation site from $3 \mathrm{~h}$ p.i. on until their division shows that the cells that eventually divide receive a trigger from rhizobia long before division. Whether induction of the flavonoid pathway is a necessary secondary signal for cell division in the inner cortex will have to be investigated. The fact that non-nodulating rhizobia were unable to induce the pathway strengthens the arguments for an involvement of flavonoids in the signal transduction pathway leading to nodule initiation. Even if necessary, the induction of the flavonoid pathway in the inner cortex alone is not sufficient for cell division in those cells, because single inoculations with LCOs induced CHS3:gusA expression and fluorescent product accumulation in the inner cortex, but no cell divisions were observed unless further LCOs were applied.

\section{Evidence that the induced orange fluorescent product is a flavonoid.}

The fluorescence emission spectrum of the compound that accumulates after the rapid induction of CHS3:gusA was sen- sitive to the application of DPBA and $\mathrm{NH}_{4} \mathrm{OH}$, suggesting that it is a flavonoid. Its location in the vacuoles suggests that the compound is a glycoside, because glycosides, in particular of flavonoids, are generally stored in plant vacuoles (Stafford 1990). A water-soluble compound was isolated from root extracts of inoculated and control roots that had fluorescence emission spectra nearly identical to those of the fluorescent vacuole contents. This compound was shown to be a derivative of DHF (Fig. 4). DHF and DHF glycosides have been isolated from clover roots and root extracts (Redmond et al. 1986 and references therein) but we have determined for the first time their cellular location. The DHF derivative was also found in control roots behind the root tip, but its synthesis appeared to be re-initiated in mature cortex cells underlying the inoculation site specifically by clover-specific rhizobia or their LCOs.

\section{Flavonoids are markers for cellular ontogeny and possible positional signals.}

The orange fluorescing inner cortex cells were highly likely to be the progenitor cells of a nodule primordium because they occurred at the site where a nodule primordium arose with a $>90 \%$ probability and they could be seen as a group of fluorescent cells surrounding the dividing cells (Fig. 2D and E). Therefore, it is possible that the specific location of the DHF derivative in inner cortex cells may be a positional signal in the newly dividing and redifferentiating cells. If the fluorescing compounds induced in the nodule progenitor cells of other legumes (pea, alfalfa, and siratro) are also flavonoids this would add weight to the hypothesis that flavonoid induction may be a general positional signal. At present, the fluorescent compounds in the nodule progenitor cells are at least a useful marker for nodule ontogeny. We are currently investigating whether flavonoid induction is a necessary requirement for nodulation by examining the development of fluorescence accumulation in nodulation-defective plant mutants.

Distinct types of fluorescence emission spectra were seen in the cells participating in nodule formation that marked either cortex cells before division or the nodule primordium cells (Figs. 3 and 5). The fluorescence spectra of cell contents of inner cortex cells before and just after division were similar, suggesting that inner cortex cells initially retained the DHF derivative after cell division. The orange fluorescence gradually disappeared in cells constituting the core of the nodule primordium, suggesting breakdown of the DHF derivative to a nonfluorescing product, or release of the DHF derivative from the vacuoles, or its conversion to another compound. Consistent with this observation, during formation of the primordium, the cells started to accumulate the isoflavonoid formononetin (Fig. 5), which has previously been found in white clover roots but had not been localized to particular cell types (Redmond et al. 1986). Cells on the periphery of the nodule primordium that are likely to be "recruited" into the nodule (Libbenga and Harkes 1973) were characterized by orange fluorescence with a spectrum slightly different from that recorded from the presumed nodule progenitor cells in the inner cortex. It is possible that the outer cortex cells contained a mixture of the DHF derivative and other fluorescing substance(s) not yet identified. Collectively, our results suggest that a tight regulation of flavonoid pathway induction occurs during nodule initiation, marking cells of different develop- 
mental stages with different end products. The accumulation of fluorescent products in the outer cortical cells of clover inoculated with foreign rhizobia appears to be a nonspecific response.

\section{Possible roles for intracellular flavonoids during nodule initiation.}

A well-known function of flavonoids that are exuded from legume roots is the activation of the nodulation (nod) genes of Rhizobium (Redmond et al. 1986). One major nod gene activator exuded from white clover roots is DHF (Djordjevic et al. 1987; Redmond et al. 1986). It has also been shown that flavonoids are exuded from cells just behind the root tip and that flavonoid production is developmentally regulated during plant growth (Djordjevic et al. 1997; Zuanazzi et al. 1998). Consistent with this, we found the DHF derivative in control and inoculated roots in specific cells just behind the root tip. It is also likely that the accumulation of that DHF derivative behind the root tip and the site of inoculation is accompanied by the release of the aglycone, DHF, because small amounts of DHF were detected in root extracts (data not presented). It is possible that this free DHF is made concurrently with the DHF derivative or as breakdown product after the DHF derivative accumulates in the vacuole. In subterranean clover, DHF exudation has been detected as a response to infection by $R$. leguminosarum bv. trifolii (Lawson et al. 1996). The exudation of DHF from inner cortex cells could create a chemotactic gradient for rhizobia and provide a constant production of nod gene inducers for the bacteria in the infection thread and a sustained production of LCOs during the early infection process (Sharma and Signer 1990). Formononetin has been identified as an anti-inducer of $R$. leguminosarum bv. trifolii nod genes in white clover (Djordjevic et al. 1987) and could turn off nod gene expression in the vicinity of the primordium.

Because we found a high correlation of the occurrence of the DHF derivative with cortex cells that are preparing for division or have just undergone division, it is possible that either this DHF derivative or released DHF has a role in cell division. It has been shown that flavonoids and flavonoid glycosides can inhibit or activate IAA (indoleacetic acid) oxidase and therefore change the turnover of auxin, a crucial phytohormone for cell division and differentiation (Furuya et al. 1962; Stenlid 1963). It will have to be investigated whether DHF glycoside or DHF has the ability to modulate auxin levels.

A change in auxin levels has been suggested to occur during the early stages of nodulation (Mathesius et al. 1998). It has been suggested that flavonoid aglycones could mediate changes in auxin accumulation as a result of auxin transport inhibition (Hirsch 1992; Mathesius et al. 1998). Our results show that flavonoid accumulation occurs very early and is site specific, which would be expected if flavonoids act as the proposed auxin transport inhibitors. The fact that only nodulating rhizobia or their LCOs could induce both the flavonoid pathway in cells participating in nodule initiation (this study) and auxin transport inhibition (Mathesius et al. 1998) is consistent with the above hypothesis. Further experiments are required to investigate this possibility.

Overall, the tight correlation of flavonoid occurrence with cell division and differentiation shows that intracellular flavonoids may have a role in nodule organogenesis in addition to the established role of exuded flavonoids as nod gene inducers.

\section{MATERIALS AND METHODS}

\section{Rooted leaf assay.}

Rooted leaves of Trifolium repens cv. Haifa were generated following a technique by Rolfe and McIver (1996) under growth conditions described elsewhere (Mathesius et al. 1998). Roots of wild-type rooted leaves were used for fluorescence measurements, and rooted leaves of transgenic plants for $\beta$-glucuronidase (GUS) assays.

\section{Generation of transgenic plants.}

Transformed white clover plants (T. repens cv. Haifa) were generated with Agrobacterium tumefaciens-mediated transformation (Larkin et al. 1996). In the CHS3:gusA reporter construct, approximately $1.2 \mathrm{~kb}$ of sequence to the $5^{\prime}$ side of the initiator methionine of the T. subterraneum CHS3 gene was fused at the initiator methionine to the E. coli gusA coding sequence, which, in turn, was linked at the $3^{\prime}$ end to approximately $300 \mathrm{bp}$ of $3^{\prime}$-terminator sequence from the pea vicilin gene (Djordjevic et al. 1997). This chimeric reporter gene was cloned into the unique EcoRI site between the TDNA borders of pTAB10 (Khan et al. 1994). The resulting plasmid, pJJ403, was transferred into the A. tumefaciens strain AGL1 (Lazo et al. 1991) for clover transformation. Transgenic plants were selected and tested for stable expression before they were grown in pots in the greenhouse under natural light conditions at temperatures between $26^{\circ} \mathrm{C}$ (day) and $19^{\circ} \mathrm{C}$ (night). Five CHS3:gusA first-generation transgenic lines were used to prepare clonal rooted leaves for analysis of transgene expression.

\section{Germination of seedlings.}

Seeds of alfalfa (Medicago sativa cv. Hunter River), siratro (Macroptilium atropurpureum; both from J. H. Williams, seed merchants, Murwillumbah, NSW, Australia), soybean (Glycine max cv. Bragg; gift from D. Day, ANU), and pea (Pisum sativum cv. Finale; gift from Muriel Sagan, INRA, Dijon, France) were surface sterilized in $70 \%$ ethanol for 5 $\mathrm{min}$, followed by 5 to $15 \mathrm{~min}$ of sterilization in $1 \%$ (wt/vol) $(0.5 \%$ for $G$. max) hypochlorite solution, and rinsed five times with sterile, distilled water. Seedlings were germinated on petri dishes containing Bergensen's modified medium (Rolfe et al. 1980) in the dark at $28^{\circ} \mathrm{C}$ (G. $\max$ and M. atropurpureum), $25^{\circ} \mathrm{C}$ ( $P$. sativum), or $21^{\circ} \mathrm{C}$ (M. sativa) for 2 days. Germinated seedlings were transferred to petri dishes containing nitrogen-free Jensen's medium (Jensen 1942) and grown for $24 \mathrm{~h}$ at $21^{\circ} \mathrm{C}(16 \mathrm{~h}$ day $)$ and $19^{\circ} \mathrm{C}(8 \mathrm{~h}$ night $)$ in a growth chamber at $140 \mu \mathrm{E} \mathrm{s}^{-1} \mathrm{~m}^{-2}$ before spot inoculation.

\section{Spot inoculation.}

Spot inoculation was done as described in Mathesius et al. (1998). The strains used to spot inoculate clover are listed in Table 1. The R. leguminosarum bv. viciae strain ANU300 (Djordjevic et al. 1986) was also used to inoculate pea, $S$. meliloti 1021 (Sharma and Signer 1990) for alfalfa, S. meliloti NGR234 for siratro, and B. japonicum 110 (Schmidt et al. 1994) for soybean.

\section{Isolation of LCOs.}

LCOs of $R$. leguminosarum bv. trifolii ANU843 were isolated following a modification of the method of Spaink et al. (1995) developed in our laboratory by L. Roddam. LCOs were 
suspended in $1 \%$ dimethyl sulfoxide (DMSO) and spot inoculated at a concentration of $10^{-8} \mathrm{M}$.

\section{Microscopy, sectioning, and histochemistry.}

Root segments consisting of $5 \mathrm{~mm}$ around the inoculation site were embedded in 3\% low melting point agarose (Sigma Chemicals, St. Louis, MO), sectioned transversely on a vibratome (Lancer Series 1000) and mounted on glass slides in distilled water. Sections had the following thicknesses: 100 $\mu \mathrm{m}$ ( $T$. repens and M. sativa), $120 \mu \mathrm{m}$ (M. atropurpureum and G. max), and $140 \mu \mathrm{m}$ (P. sativum). Maximum cortical cell lengths of each species were first determined in longitudinal sections. The thickness of transverse sections was then set to ensure that there were intact cells throughout the sections. Observation of cytoplasmic streaming in both fluorescent and nonfluorescent cells demonstrated that they were still living after sectioning, confirming that the localized accumulation of fluorescent substances was not a result of selectively cutting cells of different sizes. Sections were viewed for fluorescence at $365 \mathrm{~nm}$ with a Olympus Vanox microscope equipped with epifluorescence optics and a mercury arc lamp (HBO 200W). The filters used were a UG-1 excitation filter, DM-400 dichroic mirror, and L-420 barrier filter. For every stage of nodule development described, a minimum of five roots were examined. For photography, sections showing high cell wall fluorescence were counter stained with toluidine blue $(\mathrm{pH} 4.4$; O'Brien and McCully 1981) so that cell walls appeared dark. Sections used for microspectrofluorometry were not stained with toluidine blue, so UV spectra recorded of cell contents were not affected by this dye. Photographs were taken on Agfachrome RSX100 color slide film.

For histochemical GUS assays, roots were stained as described in Larkin et al. (1996), photographed as whole roots under a Nikon SMZ-10 stereo microscope, or sectioned as described above, and sections were photographed under a Nikon Optiphot microscope with Kodak Ektachrome color slide film.

\section{Flavonoid-specific reactions on root sections.}

Fresh sections were incubated either with diphenylboric acid-2-aminoethyl ester (DPBA; Sigma), as described in Djordjevic et al. (1997) or with $0.5 \% \mathrm{NH}_{4} \mathrm{OH}$ (Schnabl et al. 1986) for $5 \mathrm{~min}$ before viewing for fluorescence or before microspectrofluorometry.

\section{Microspectrofluorometry.}

Fresh vibratome sections of rooted leaves of white clover plants were mounted in distilled water on quartz microscope slides under quartz cover slips (Ted Pella, Inc., Redding, CA). Scanning of cell wall fluorescence was largely avoided, but could not be completely excluded in the measurements of live tissue. Emission spectra of fluorescent cell contents of single cells were recorded with a Leitz MPV-SP microspectrophotometer with a Leitz Aristomed epifluorescence microscope equipped with a Leitz PL Fluotar 50× Objective, a 75 W XBO xenon arc lamp, and an MPV kombi photomultiplier. The excitation wavelength was $365 \mathrm{~nm}$. Before measurement of cellular fluorescence, an emission spectrum was recorded from a nonfluorescent part of the section, and this "background" spectrum was subsequently subtracted from the fluorescence emission spectra of fluorescent cell contents. A faint green autofluorescence of DPBA and $\mathrm{NH}_{4} \mathrm{OH}$ was equally sub- tracted as a background from emission spectra of sections treated with those reagents. Every cell was scanned 64 times over a square area of $10 \times 10 \mu \mathrm{m}^{2}$ with a rectangular adjustable diaphragm, and the measurements were averaged. Emission was measured every $1 \mathrm{~nm}$ over a range of 400 to $700 \mathrm{~nm}$. The software used was Espectre from Leitz. For every cell type and timepoint, spectra were recorded of at least 5 different comparable cells of different roots. Spectra were only presented when all cells of a comparable stage showed the features (emission maxima and ratio of peaks) of that spectrum.

\section{Flavonoid extraction and identification.}

Roots of rooted leaves were cut off the plantlets, weighed, immediately frozen in liquid nitrogen, and finely ground. The powder was mixed with HPLC-grade methanol, using $2 \mathrm{ml}$ of methanol for every $100 \mathrm{mg}$ of fresh weight tissue. After vigorous shaking and centrifugation for $10 \mathrm{~min}$ at 7,000 rpm (Sorvall RC-5C centrifuge, Du Pont, Wilmington, DE), the supernatant was removed and evaporated under a nitrogen stream, and the remaining substance redissolved in HPLCgrade methanol at $100 \mu \mathrm{l}$ per $\mathrm{g}$ of tissue. The root extract components were separated on a Hewlett Packard 1090 liquid chromatograph equipped with a $\mathrm{C}-18$ column (Alltech Alltima, $250 \mathrm{~mm} \times 4.6 \mathrm{~mm}$ ) with the following solvents: $\mathrm{A}=\mathrm{ul}-$ tra-pure water (Millipore, North Ryde, Australia) containing $0.09 \%$ trifluoroacetic acid; $\mathrm{B}=$ acetonitrile containing $0.09 \%$ trifluoroacetic acid. The column was eluted isocratically with solvent A for $5 \mathrm{~min}$ and a linear gradient of 0 to $100 \% \mathrm{~B}$ between 5 and $25 \mathrm{~min}$ at ambient temperature with a flow rate of $1 \mathrm{ml} / \mathrm{min}$. Eluting compounds were monitored at 275 and 300 $\mathrm{nm}$ with a diode array detector and, subsequently, fluorescence was detected at $450 \mathrm{~nm}$ (365 nm excitation) with an HP 1046 fluorescence detector. DHF and formononetin (Indofine Chemicals, Belle Mead, NJ) were used as standards.

Eluting compounds were collected, dried down under a nitrogen stream, and resuspended in $50 \mu \mathrm{l}$ of water. Each suspended compound was transferred to a small glass vial protected from light and placed under the microspectrofluorometer to record the emission spectrum.

Compounds were hydrolyzed in boiling $6 \% \mathrm{HCl}$ for $1 \mathrm{~h}$. The aglycone was extracted by shaking the sample with diethyl ether, then evaporating under nitrogen gas. The aglycone was resuspended in methanol and analyzed by HPLC under the above conditions.

\section{Statistical analysis.}

One way analysis of variance was done with Microsoft Excel 5.0.

\section{ACKNOWLEDGMENTS}

U. M. was supported by an Overseas Postgraduate Research Scholarship from the Australian Government. U. M.'s work in Canada was supported by an operating grant to M. E. M. from the Natural Sciences and Engineering Research Council of Canada. We thank M. Stoilovic (The Australian Federal Police, Weston, ACT) and L. N. Pietrzak (Agriculture and Agrifoods Canada) for the use of and help with their respective microspectrofluorometers.

\section{LITERATURE CITED}

Arioli, T., Howles, P. A., Weinman, J. J., and Rolfe, B. G. 1994. In Trifolium subterraneum, chalcone synthase is encoded by a multigene 
family. Gene 138:79-86.

Bauer, P., Ratet, P., Crespi, M. D., Schultze, M., and Kondorosi, A. 1996. Nod-factors and cytokinins induce similar cortical cell divisions, amyloplast deposition and MsENOD12A expression patterns in alfalfa roots. Plant J. 10:91-105.

Bayliss, C., Canny, M. J., and McCully, M. E. 1997. Retention in situ and spectral analysis of fluorescent vacuole components in sections of plant tissue. Biotech. Histochem. 72:123-128.

Charrier, B., Coronado, C., Kondorosi, A., and Ratet, P. 1995. Molecular characterisation and expression of alfalfa (Medicago sativa L.) flavanone-3-hydroxylase and dihydroflavonol-4-reductase encoding genes. Plant Mol. Biol. 29:773-786.

Dénarié, J., Débellé, F., and Promé, J. C. 1996. Rhizobium lipochitooligosaccharide nodulation factors: Signaling molecules mediating recognition and morphogenesis. Annu. Rev. Biochem. 65:503-535.

Djordjevic, M. A., Innes, R. W., Wijffelman, C. A., Schofield, P. R., and Rolfe, B. G. 1986. Nodulation of specific legumes is controlled by several distinct loci in Rhizobium trifolii. Plant Mol. Biol. 6:389-401.

Djordjevic, M. A., Mathesius, U., Arioli, T., Weinman, J. J., and Gärtner, E. 1997. Chalcone Synthase gene expression in transgenic subterranean clover correlates with localised accumulation of flavonoids. Aust. J. Plant Physiol. 24:119-132.

Djordjevic, M. A., Redmond, J. W., Batley, M., and Rolfe, B. G. 1987. Clovers secrete specific phenolic compounds which either stimulate or repress nod gene expression in Rhizobium trifolii. EMBO J. 6:1173-1179.

Furuya, M., Garlston, A. W., and Stowe, B. B. 1962. Isolation from peas of co-factors and inhibitors of indolyl-3-acetic acid oxidase. Nature 193:456-457.

Hirsch, A. M. 1992. Developmental biology of legume nodulation. New Phytol. 122:211-237.

Hirsch, A. M., Bhuvaneswari, T. V., Torrey, J. G., and Bisseling, T. 1989. Early nodulin genes are induced in alfalfa root outgrowths elicited by auxin transport inhibitors. Proc. Natl. Acad. Sci. USA 86: 1244-1248

Jacobs, M., and Rubery, P. H. 1988. Naturally occurring auxin transport regulators. Science 241:346-349.

Jensen, H. L. 1942. Nitrogen fixation in leguminous plants I. General characters of root nodule bacteria isolated from species of Medicago and Trifolium in Australia. Proc. Linn. Soc. NSW 67:98-108.

Khan, M. R. I., Tabe, L. M., Heath, L. C., Spencer, D., and Higgins, T. J. V. 1994. Agrobacterium-mediated transformation of subterranean clover. Plant Physiol. 105:81-88.

Krause, A., Lan, T. T. V., and Broughton, W. J. 1997. Induction of chalcone synthase expression by rhizobia and Nod factors in root hairs and roots. Mol. Plant-Microbe Interact. 10:388-393.

Larkin, P. J., Gibson, J. M., Mathesius, U., Weinman, J. J., Gärtner, E., Hall, E., Tanner, G. J., Rolfe, B. G., and Djordjevic, M. A. 1996. Transgenic white clover. Studies with the auxin responsive promoter, $G H 3$, in root gravitropism and lateral root development. Transgenic Res. 5:325-335.

Lawson, C. G. R., Djordjevic, M. A., Weinman, J. J., and Rolfe, B. G. 1994. Rhizobium inoculation and physical wounding result in the rapid induction of the same chalcone synthase copy in Trifolium subterraneum. Mol. Plant-Microbe Interact. 7:498-507.

Lawson, C. G. R., Rolfe, B. G., and Djordjevic, M. A. 1996. Rhizobium inoculation induces condition dependent changes in the flavonoid composition of root exudates from Trifolium subterraneum. Aust. J. Plant Physiol. 23:93-101.

Lazo, G. R., Stein, P. A., and Lugwig, R. A. 1991. A DNA transformation-competent Arabidopsis genomic library in Agrobacterium. Bio/Technology 9:936-967.

Libbenga, K. R., and Harkes, P. A. A. 1973. Initial proliferation of cortical cells in the formation of root nodules in Pisum sativum L. Planta 114:17-28.

Mathesius, U., Schlaman, H. R. M., Spaink, H. P., Sautter, C., Rolfe, B.
G., and Djordjevic, M. A. 1998. Auxin transport inhibition precedes root nodule formation in white clover roots and is regulated by flavonoids and derivatives of chitin oligosaccharides. Plant J. 13:23-34.

McKay, I. A., and Djordjevic, M. A. 1993. Production and excretion of nod metabolites by Rhizobium leguminosarum bv. trifolii are disrupted by the same environmental factors that reduce nodulation in the field. Appl. Environ. Microbiol. 59:3385-3392.

McKhann, H. I., Paiva, N. L., Dixon, R. A., and Hirsch, A. M. 1997. Chalcone synthase transcripts are detected in alfalfa root hairs following inoculation with wild-type Rhizobium meliloti. Mol. PlantMicrobe Interact. 10:50-58.

O'Brien, T. P., and McCully, M. E. 1981. The Study of Plant Structure: Principles and Selected Methods. Termarcarphi, Melbourne, Australia.

Pietrzak, L. N., and Collins, F. W. 1996. Comparison of fluorometric reagents for microspectrofluorometric determination of flavonoid glycosides in wheat germ. J. Cereal Sci. 23:85-91.

Recourt, K., van Tunen, A. J., Mur, L. A., van Brussel, A. A. N., Lugtenberg, B. J. J., and Kijne, J. W. 1992. Activation of flavonoid biosynthesis in roots of Vicia sativa subsp. nigra plants by inoculation with Rhizobium leguminosarum biovar viciae. Plant Mol. Biol. 19: 211-220.

Redmond, J. R., Batley, M., Djordjevic, M. A., Innes, R. W., Keumpel, P. L., and Rolfe, B. G. 1986. Flavones induce expression of nod genes in Rhizobium. Nature 323:632-635.

Rolfe, B. G., Gresshoff, P. M., and Shine, J. 1980. Rapid screening for symbiotic mutants of Rhizobium and white clover. Plant Sci. Lett. 19: 277-284.

Rolfe, B. G., and McIver, J. 1996. Single-leaf plantlet bioassays for the study of root morphogenesis and Rhizobium nodulation. Aust. J. Plant Physiol. 23:271-283.

Savouré, A., Sallaud, C., Elturk, J., Zuanazzi, J., Ratet, P., Schultze, M., Kondorosi, A., Esnault, R., and Kondorosi, E. 1997. Distinct responses of Medicago suspension cultures and roots to Nod factors and chitin oligomers in the elicitation of defence and related responses. Plant J. 11:277-287.

Schmidt, P. E., Broughton, W. J., and Werner, D. 1994. Nod-factors of Bradyrhizobium japonicum and Rhizobium sp. NGR234 induce flavonoid accumulation in soybean root exudate. Mol. Plant-Microbe Interact. 7:384-390.

Schnabl, H., Weissenböck, G., and Scharf, H. 1986. In vivo-microspectrophotometric characterisation of flavonol glycosides in Vicia faba guard and epidermal cells. J. Exp. Bot. 37:61-72.

Sharma, S. B., and Signer, E. R. 1990. Temporal and spatial regulation of the symbiotic genes of Rhizobium meliloti in planta revealed by transposon Tn5-gusA. Genes Dev. 4:344-356.

Spaink, H. P. 1996. Regulation of plant morphogenesis by lipo-chitin oligosaccharides. Crit. Rev. Plant Sci. 15:559-582.

Spaink, H. P., Bloemberg, G. V., van Brussel, A. A. N., Lugtenberg, B. J. J., van der Drift, K. M. G. M., Haverkamp, J., and Thomas-Oates, J. E. 1995. Host specificity of Rhizobium leguminosarum is determined by the hydrophobicity of highly unsaturated fatty acyl moieties of the nodulation factors. Mol. Plant-Microbe Interact. 8:155-164.

Stafford, H. A. 1990. Flavonoid Metabolism. CRC Press, Boca Raton, FL.

Stenlid, G. 1963. The effects of flavonoid compounds on oxidative phosphorylation and on the enzymatic destruction of indoleacetic acid. Physiol. Plant. 16:110-121.

Yang, W. C., Canter-Cremers, H. C. J., Hogendijk, P., Katinakis, P., Wijffelman, C. A., Franssen, H., Van Kammen, A., and Bisseling, T. 1992. In-situ localisation of chalcone synthase mRNA in pea root nodule development. Plant J. 2:143-151

Zuanazzi, J. A. S., Clergeot, P., Quirion, J.-C., Husson, H.-P., Kondorosi, A., and Ratet, P. 1998. Production of Sinorhizobium meliloti nod gene activator and repressor flavonoids from Medicago sativa roots. Mol. Plant-Microbe Interact. 8:784-794. 